\title{
Utilization of Salicornia fruticosa herb for producing antioxidants
}

\author{
*E. M. Elsebaie, S. Y. A. Elsanat, M. S. Gouda and K. M. EInemr \\ Food Technology Department, Faculty of Agric. Kafrelsheikh University, Egypt
}

\begin{abstract}
The present work was aimed to study the effect of extracted phenolic compounds from Salicornia air part by several solvents as natural antioxidants on preservation of corn oil comparing with synthetic antioxidant (TBA) on the oil stability against oxidative rancidity during storage at $70{ }^{\circ} \mathrm{C}$ for 5 days. The results indicate that the best solvent for extracting polyphenolic compounds was methanol followed by ethanol, chloroform and water. HPLC analysis for the total polyphenols extracted from the air part of salicornia fruticosa indicated to presence high percentages of Pyrogallol, Ellagic, B-OH Benzoic and Catechin. The extracted phenolic acids were tested against corn oil keeping quality. Results show that peroxide value and TBA values of corn oil that treated by different types of extracts at different levels were lower than control. Keywords: Salicornia fruticosa; DPPH; Corn oil; Phenolic extract.
\end{abstract}

Keywords: Salicornia fruticosa; DPPH; Corn oil; Phenolic extract.

\section{Introduction}

There is a growing body of evidence suggesting that oxidative stress through an increased production of reactive oxygen and nitrogen species (ROS and RNS) plays an important role in the development of tissue damage and pathological events in living organisms (Peuchant et al., 2004).

In order to limit the harmful effects of ROS, a high performance antioxidant system, consisting of enzymes, proteins, vitamins, carotenoids, polyphenols, trace elements and small molecules, such as glutathione, may interact with ROS and regulate their production within a physiological range.

Antioxidants may therefore be of major importance in preventing the onset and/or the progression of oxidative pathologies and may provide protection to foods (Spignoli, 2000). The physiological benefits of the plant phenolics have been attributed to their potential role in inhibiting lipid peroxidation, modulating cell signal transduction pathways and inducing apoptosis (Hou et al., 2004). The development and utilisation of more effective antioxidants of natural origin could, therefore, afford potential benefits for the optimization of human health (Moure et al., 2001; Panico et al., 2005). Increased concern over the safety of synthetic antioxidants like butylated hydroxyanisole (BHA) and butylated hydroxytoluene (BHT) (Tsuda et al., 1998) has lead to an increased interest in exploration of effective and economical natural antioxidants. There is increasing evidence that changing one's diet to an increased intake of food in selected natural antioxidants, such as plant polyphenols, vitamin $\mathrm{C}$ or flavonoids, can reduce the incidence of chronic and degenerative diseases (Laandrault et al., 2001). Several sources of natural antioxidants have been investigated, including plants and microorganisms (Arai et al., 2002 and Bandoniene et al., 2000). The extraction and purification of phytochemicals from natural sources is desired, since these bioactive substances are often used in the preparation of dietary supplements, nutraceuticals, functional food ingredients, food additives, pharmaceuticals and cosmetic products (Radwan et al., 2007). Different solvent systems have been used for extraction of polyphenols from plant materials (Chavan et al., 2001). Extraction yield is dependent on the solvent and method of extraction (Goli et al., 2005). The extraction method must enable complete extraction of the compounds of interest and must avoid their chemical modification (Zuo et al., 2002).

Salicornia fruticosa L. (also known as glasswort) is annual succulent herb of Chenopodiaceae family and one of the most salt tolerant plants. It is growing on salt marshes and muddy seashores (Kim et al., 2009) and this family is represented in Egypt by 25 genera and about 300 species. Several species possess antibacterial and antihypertensive properties,

*Corresponding author. e-mail: essamelsbay@yahoo.com 
also mentioned in folk medicine for relief of toothache and chronic rheumatic. Investigation of certain species of this family revealed that they contain large amounts of minerals, essential amino acid, essential fatty acids, coumarins, phenolic compounds and alkaloids (Radwan et al., 2007).

The aim of this study is to isolate Phenolic compounds extracted from Salicornia fruticosa, then identify and using it as natural antioxidants for preservation corn oil during storage.

\section{Materials and methods}

\section{Materials}

Salicornia fruticosa (L.) was collected from international coastal road near El- Boroles city, Kafr El- Sheikh Governorate, Egypt during January 2012. The plant was identified by Dr. M. El-Gebaly and Dr. S. El Kawasshty, taxonomists, National Research Center, Cairo, Egypt (Radwan et al., 2007). Corn oil was obtained from Tanta company for oils and soaps, Tanta, Egypt. Commercial antioxidant; butylated hydroxyanisole (BHA) and 1,1-diphenyl-2-picrylhydrazyl (DPPH) were purchased from Sigma chemical company (St. Louis, Mo., U.S.A.). All chemicals and solvents used in this investigation (HPLC spectral grade) were purchased from El- Gomhorea company, Tanta, Egypt.

\section{Methods}

Sample preparation for antioxidant extracts:

After roots separation, the air part of the plant were cut into small pieces $(1 \mathrm{~cm})$ then dried at $40^{\circ} \mathrm{C} \pm 2{ }^{\circ} \mathrm{C}$ in an air hot oven until the moisture content reached less than $10 \%$. The dried product was ground into powder to pass through a 60 mesh sieve. These fractions were used in analyses for the chemical composition.

\section{Gross chemical composition}

Moisture; crude protein; ether extract; ash and crude fiber content were determined according to the methods described in the A. O.A. C. ( 2000). Total carbohydrates were calculated by difference.

\section{Total phenolic compounds determination}

\section{Extraction of total phenolic compounds}

The prepared ground sample (5 g) were macerated in $50 \mathrm{~mL}$ of each solvent ( absolute methanol, ethanol, chloroform and water) for 24 hours at room temperature. The crude solvent extracts were filtrated through filter paper (Whatman No. 1), filtrates were evaporated under vacuum in rotary evaporator at $45^{\circ} \mathrm{C}$ and weighted to determine the extracted yield of each sample (McGrath et al., 1982).

\section{Quantitative determination of total Phenolic compounds}

The concentrations of total phenols in each extract were estimated with Folin-Ciocalteau reagent (Gutfinger, 1981).

\section{HPLC determination and identification of Phenolic com-} pounds

Phenolic compounds of samples were extracted according to the method outlined by Evangelisti, et al.(1995). A known weight of dried powder sample was soaked in $25 \mathrm{ml}$ sterilized water and agitated on a rotary shaker for $24 \mathrm{hrs}$ at $200 \mathrm{rpm}$. Sullary was filtered through WhatmanNo3 filter paper under vacuum, followed by centrifugation at $12.500 \mathrm{~g}$ for $30 \mathrm{~min}$ at $80^{\circ} \mathrm{C}$. The aqueous extract was acidified to $\mathrm{pH}(2.5)$ using diluted phosphoric acid. Each sample was partitioned three times with an equal volume of diethyl -ether. The combined diethyl -ether layers were evaporated to dryness under reduced pressure at $30^{\circ} \mathrm{C}$. The resulting residue was redissolved in $3 \mathrm{ml}$ of spectral grade methanol and filtered through a $0.2 \mu \mathrm{m}$ filter sterilized membrane prior HPLC analysis.

Identification of individual Phenolic compounds of the plant samples were performed on a HEWLLET packared HPLC (Model 1100), using a hypersil C18 reversed-phase column $(250 \times 4.6 \mathrm{~mm})$ with $5 \mu \mathrm{m}$ particle size. Injection by means of a Rheodyne injection valve (Model 7125) with $5 \mu$ l fixed loop was used. A constant flow rate of one $\mathrm{ml} / \mathrm{min}$ was used with two mobile phases: (A) $0.5 \%$ acetic acid in distilled water at $\mathrm{pH} 2.65$; and solvent (B) $0.5 \%$ acetic acid in $99.5 \%$ acetonitrile. The elution gradient was linear starting with (A)and ending with (B)over $35 \mathrm{~min}$, using an UV detector set at wavelength $254 \mathrm{~nm}$. Phenolic compounds of each sample were identified by comparing their relative retention time with those of the standards mixture chromatogram. The concentration of an individual compound was calculated on the basis of peak area measurements, and then converted to $\mu \mathrm{g}$ Phenolic /g dry weight. Sixteen standard Phenolic compounds were purchased from Sigma (St. Louis, USA) and from Merck-Schuchardt (Munich, Germany) Chemical Companies. 
Scavenging effect assay of Salicornia fruticosa air part extracts

The free radical scavenging activity of all the extracts was evaluated by 1, 1-diphenyl-2-picryl-hydrazyl (DPPH) according to the method of Sousa et al. (2008). . Briefly, an $0.1 \mathrm{mM}$ solution of DPPH in methanol was prepared, and $1 \mathrm{~mL}$ of this solution was added to $3 \mathrm{~mL}$ of the solution of all extracts at different concentration (100 \& 200 $\mathrm{ppm}$ ). The mixtures were shaken vigorously and allowed to stand at room temperature for 30 minutes. Then the absorbance was measured at $517 \mathrm{~nm}$ using a UV-VIS spectrophotometer (Genesys10S UV: Thermo electron corporation). Butylated hydroxyanisole (BHA) was used as the reference. Lower absorbance values of reaction mixture indicate higher free radical scavenging activity. The capability to scavenging the DPPH radical was calculated by using the following formula. malondialdhyde/ kg oil.

Statistical analysis

Data were treated by analysis of variance (ANOVA) using the SAS ANOVA procedure (Statistical analysis system, 1988). Duncan's multiple range test (Duncan 1955) was used to compare differences among individual means. Treatment effects were considered significant at $\mathrm{P} \leq 0.05$ levels.

\section{Results and discussion}

Gross chemical composition of Salicornia fruticosa air part:

Table (I) shows gross chemical composition of salicornia fruticosa air part. Data indicate that moisture, crude protein, ether extract, ash, crude fiber and available carbohydrate of salicornia fruticosa air part were 77.63, 18.04, 14.69, 13.39,

Table I. Gross chemical composition of Salicornia fruticosa air part (\%on dry weight basis)

\begin{tabular}{lcccccc}
\hline Component $(\%)$ & Moisture & Crude protein & Ether extract & Ash & Crude fiber & available carbohydrate* \\
\hline $\begin{array}{l}\text { salicornia } \\
\text { fruticosa } \text { air part }\end{array}$ & 77.63 & 18.04 & 14.69 & 13.39 & 30.65 & 23.23 \\
\hline
\end{tabular}

*Total carbohydrates were calculated by difference

$\%$ scavenging effect $=\left[\left(\mathrm{A}_{\mathrm{DPPH}}-\mathrm{A}_{\mathrm{S}}\right) / \mathrm{A}_{\mathrm{DPPH}}\right] \times 100$

Where $A_{S}$ is the absorbance of the solution when the sample extract has been added at a particular level, and $\mathrm{A}_{\mathrm{DPPH}}$ is the absorbance of the DPPH solution.

\section{Antioxidative efficiency of Salicornia fruticosa extracts}

The antioxidative activities of polyphenol extracts from Salicornia fruticosa were assayed by addition of each extracts $0,100,200,300 \mathrm{ppm}$ to corn oil (control), then Pyrex bottles filled up with treated oils. The treated oils were stored in an air oven at $70^{\circ} \mathrm{C}$ for five days and the degree of oxidation was determined at different times as follows:

Peroxide values $(\mathrm{PV})$

The peroxide values (PV) of stored oils were determined as described by Leonard et al., (1987). Expressed as millequivalents of peroxide per $1000 \mathrm{~g}$ of sample.

\section{Thiobarbituric acid number (TBA)}

Thiobarbituric acid values were carried out according to the method described by Sidwell et al. (1990). Expressed as mg
30.65 and $23.23 \%$ respectively. These results are in agreement with those reported by Min et al. (2002) and Lee et al. (2004).

Effect of using different solvents on extraction yield and total polyphenol content extracted from salicornia fruticosa air part

Extraction yield and total polyphenol content extracted from salicornia fruticosa air part are given in Table II. The data indicate that water used as extraction solvent was the highest

Table II. Effect of different solvents on extraction yield and total polyphenol content extracted from salicornia fruticosa air part

\begin{tabular}{lcc}
\hline Extraction solvent & $\begin{array}{c}\text { Extraction } \\
\text { yield (\%) }\end{array}$ & $\begin{array}{c}\text { Total poly } \\
\text { phenols(ppm) }\end{array}$ \\
\hline Methanol & $18.46^{\mathrm{b}}$ & $1520^{\mathrm{a}}$ \\
Ethanol & $8.76^{\mathrm{c}}$ & $1240^{\mathrm{b}}$ \\
Chloroform & $4.60^{\mathrm{d}}$ & $940^{\mathrm{c}}$ \\
Water & $48.6^{\mathrm{a}}$ & $872^{\mathrm{d}}$ \\
\hline
\end{tabular}

Values followed by the same letter in the same columns are not significantly different $\mathrm{P} \leq 0.05$ 
amount of extracted yield reaching $48.6 \%$, followed by methanol $18.46 \%$. These results are agreement with the results obtained by Kang et al. (2011). On the other hand, the data indicate that methanol was the best solvent for extracting polyphenols from salicornia fruticosa air part. High amount of extracted polyphenolic compounds by methanol was 1520 (ppm), comparing with other solvents. These results are in agreement with the results obtained by Kahkonen et al. (1999) and Min et al (2002).

Phenolic compounds extracted from salicornia fruticosa air part

High performance liquid chromatography method (HPLC) was used to fractionate and identificate the polyphenolic compounds extracted from salicornia fruticosa air part. The obtained results, were listed in Table (II).

Data in table (III) indicated that, salicornia fruticosa air part methanolic extract contains 12 phenolic compounds. Pyrogallol, Ellagic, B-OH Benzoic and Catechin were the major phenolic compounds presented and identified in the methanolic extract.

Table III. Phenolic compounds in methanolic extract of salicornia fruticosa air part

\begin{tabular}{lccc}
\hline $\begin{array}{l}\text { Phenolic } \\
\text { compound }\end{array}$ & $\begin{array}{c}\text { Concentration } \\
(\%)\end{array}$ & $\begin{array}{c}\text { Phenolic } \\
\text { compound }\end{array}$ & $\begin{array}{c}\text { Concentration } \\
(\%)\end{array}$ \\
\hline Pyrogallol & 28.14 & Caffeine & 4.38 \\
Protocatechuic & 5.16 & B- coumaric & 0.42 \\
Catechin & 10.26 & B-OH Benzoic & 10.92 \\
Chlorogenic & 8.09 & Ellagic & 25.41 \\
caffeic & 1.81 & Colchecien & 2.49 \\
Vanillic & 2.88 & Chrysin & 0.04 \\
\hline
\end{tabular}

Table IV. Antioxidant activities of various solvent extracts from salicornia fruticosa air part in DPPH assay

\begin{tabular}{lcc}
\hline Extract type & \multicolumn{2}{c}{ DPPH reduction \% } \\
& $100 \mathrm{ppm}$ & $200 \mathrm{ppm}$ \\
\hline BHA & $83.760^{\mathrm{a}}$ & $94.550^{\mathrm{a}}$ \\
Methanol extract & $57.510^{\mathrm{b}}$ & $76.060^{\mathrm{b}}$ \\
Ethanol extract & $43.427^{\mathrm{c}}$ & $60.330^{\mathrm{c}}$ \\
Chloroform extract & $34.510^{\mathrm{d}}$ & $43.896^{\mathrm{d}}$ \\
Water extract & $7.280^{\mathrm{e}}$ & $13.380^{\mathrm{e}}$ \\
\hline
\end{tabular}

Values followed by the same letter in the same columns are not significantly different $\mathrm{P} \leq 0.05$.

\section{Antioxidant activity}

Antioxidant activity of salicornia fruticosa air part extracts were analyzed measuring scavenging activities of DPPH. DPPH radical is a stable dark purple colored radical, which are changed to yellow by accepting an electron from antioxidants (Sasidharan et al., 2007). Data in table IV showed that methanolic extract has the most potent activity followed by ethanol extract, chloroform extract and water extract at the low levels of concentrations 100 and $200 \mathrm{ppm}$. These results are in agreement with the results obtained by Min et al. (2002).

Utilization of salicornia fruticosa air part phenolic extracts as natural antioxidants

Antioxidant activity of phenolic compounds extracted from salicornia fruticosa air part was assayed against corn oil (control). Measurement of peroxide value (PV) and Thiobarbituric acid (TBA) are suitable potent parameters to characterize oxidative changes in the tested oils. In this relation, different levels (100, 200 and $300 \mathrm{ppm})$ of phenolic salicornia fruticosa air part extracts were added to corn oil as natural antioxidants then PV and TBA were determined during storage for 5 days at $70{ }^{\circ} \mathrm{C}$ and compared with oil treated by 200 ppm of TBA as a synthetic antioxidant.

Effect of adding different levels of natural extracts and synthetic antioxidants on peroxide value (PV) of corn oil stored at $70^{\circ} \mathrm{C}$

Table (V) showed the change in PV of corn oil free from antioxidants and those treated with synthetics and natural antioxidants. In general, addition of such compounds caused to decrease the increment of PV compared with oil free from antioxidants. However, the results showed that PV was gradually increased storage and the level of the increase for untreated oils were greater than all samples of treated oils. These results are consistent with findings of Yanping et al. (1999) who reported that lipid peroxides were significantly reduced by the addition of antioxidants in processed foods and oil.

Effect of adding different levels of natural extracts and synthetic antioxidants on Thiobarbituric acid (TBA) of corn oil stored at $70^{\circ} \mathrm{C}$.

Thiobarbituric acid (TBA) of fresh and heated corn oil were determined and the results are presented in Table (VI). The levels of TBA values were rapidly increased with increasing the storage period of control. Comparing to heated control (3.11 $\mathrm{mg}$ malonaldhyde/ $\mathrm{kg}$ oil) for five days storage, all antioxidant extracts and BHA decreased TBA value to 1.823 , $1.859,1.983,2.155$ and $2.475 \mathrm{mg}$ malonaldhyde/kg oil. Similar results were obtained by Hassan (2002). 
Table V. peroxide value per milli-equivalent $\mathrm{O}_{2} / 1000 \mathrm{~g}$ oil (PV) of corn oil treated by Salicornia fruticosa air part phenolic extracts during storage at $70^{\circ} \mathrm{C}$

\begin{tabular}{|c|c|c|c|c|c|c|c|c|c|c|c|c|c|c|}
\hline \multirow{2}{*}{ 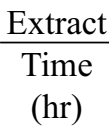 } & \multirow{2}{*}{ Control } & \multirow{2}{*}{$\begin{array}{c}\text { BHA } \\
200 \\
\text { ppm }\end{array}$} & \multicolumn{3}{|c|}{ Methanol } & \multicolumn{3}{|c|}{ Ethanol } & \multicolumn{3}{|c|}{ Chloroform } & \multicolumn{3}{|c|}{ Water } \\
\hline & & & $\begin{array}{l}100 \\
\mathrm{ppm}\end{array}$ & $\begin{array}{l}100 \\
\text { ppm }\end{array}$ & $\begin{array}{l}100 \\
\mathrm{ppm}\end{array}$ & $\begin{array}{l}100 \\
\text { ppm }\end{array}$ & $\begin{array}{c}100 \\
\text { ppm }\end{array}$ & $\begin{array}{l}100 \\
\text { ppm }\end{array}$ & $\begin{array}{l}100 \\
\text { ppm }\end{array}$ & $\begin{array}{l}100 \\
\mathrm{ppm}\end{array}$ & $\begin{array}{r}100 \\
\text { ppm }\end{array}$ & $\begin{array}{l}100 \\
\text { ppm }\end{array}$ & $\begin{array}{l}100 \\
\text { ppm }\end{array}$ & $\begin{array}{l}100 \\
\text { ppm }\end{array}$ \\
\hline 0 & 0.39 & 0.39 & 0.39 & 0.39 & 0.39 & 0.39 & 0.39 & 0.39 & 0.39 & 0.39 & 00.39 & 0.39 & 0.39 & 0.39 \\
\hline 24 & $4.62^{\mathrm{a}}$ & $3.19^{j}$ & $3.53^{\mathrm{f}}$ & $3.38^{\mathrm{h}}$ & $3.32^{\mathrm{i}}$ & $3.96^{\mathrm{c}}$ & $3.45^{\mathrm{g}}$ & $3.41^{\mathrm{g}}$ & $4.1^{\mathrm{b}}$ & $3.67^{\mathrm{e}}$ & $3.49^{\mathrm{f}}$ & $4.28^{\mathrm{b}}$ & $3.99^{\mathrm{c}}$ & $3.88^{\mathrm{d}}$ \\
\hline 48 & $5.62^{\mathrm{a}}$ & $3.86^{\mathrm{i}}$ & $4.41 \mathrm{~d}^{\mathrm{e}}$ & $4.28^{f}$ & $3.91^{\mathrm{h}}$ & $4.53^{\mathrm{c}}$ & $4.39^{\mathrm{e}}$ & $4.00^{\mathrm{g}}$ & $4.67^{\mathrm{b}}$ & $4.52^{\mathrm{c}}$ & $4.33^{\mathrm{f}}$ & $4.71^{\mathrm{b}}$ & $4.55^{\mathrm{c}}$ & $4.46^{\mathrm{d}}$ \\
\hline 72 & $6.30^{\mathrm{a}}$ & $4.14^{\mathrm{j}}$ & $4.64^{\mathrm{f}}$ & $4.47^{\mathrm{h}}$ & $4.30 \mathrm{i}$ & $4.81^{\mathrm{c}}$ & $4.63^{f}$ & $4.48^{\mathrm{h}}$ & $4.98^{\mathrm{b}}$ & $4.69^{\mathrm{e}}$ & $4.51^{\mathrm{g}}$ & $5.09^{\mathrm{b}}$ & $4.76^{\mathrm{d}}$ & $4.69^{\mathrm{e}}$ \\
\hline 96 & $8.91^{\mathrm{a}}$ & $5.878^{\mathrm{k}}$ & $6.65^{\mathrm{f}}$ & $6.42^{\mathrm{h}}$ & $6.06^{j}$ & $6.88^{\mathrm{d}}$ & $6.63^{\mathrm{f}}$ & $6.29^{\mathrm{i}}$ & $7.12^{\mathrm{c}}$ & $6.76^{\mathrm{e}}$ & $6.48^{\mathrm{g}}$ & $7.25^{\mathrm{b}}$ & $6.84^{\mathrm{d}}$ & $6.73^{\mathrm{e}}$ \\
\hline 120 & $10.783^{\mathrm{a}}$ & $7.071^{\mathrm{k}}$ & $8.014^{\mathrm{f}}$ & $7.74^{\mathrm{h}}$ & $7.29^{j}$ & $8.26^{\mathrm{d}}$ & $7.99^{f}$ & $7.57^{\mathrm{i}}$ & $8.56^{\mathrm{c}}$ & $8.13^{\mathrm{e}}$ & $7.8^{\mathrm{g}}$ & $8.7^{\mathrm{b}}$ & $8.21^{\mathrm{d}}$ & $8.08^{\mathrm{e}}$ \\
\hline
\end{tabular}

Values followed by the same letter in the same row are not significantly different $\mathrm{P} \leq 0.05$.

Table VI. Thiobarbituric acid number mg malondialdhyde/ $\mathrm{kg}$ oil (TBA)of corn oil treated by Salicornia fruticosa air part phenolic extracts during storage at $70{ }^{\circ} \mathrm{C}$

\begin{tabular}{|c|c|c|c|c|c|c|c|c|c|c|c|c|c|c|}
\hline \multirow{2}{*}{ 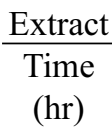 } & \multirow{2}{*}{ Control } & \multirow{2}{*}{$\begin{array}{c}1 \text { BHA } \\
200 \\
\text { ppm }\end{array}$} & \multicolumn{3}{|c|}{ Methanol } & \multicolumn{3}{|c|}{ Ethanol } & \multicolumn{3}{|c|}{ Chloroform } & \multicolumn{3}{|c|}{ Water } \\
\hline & & & $\begin{array}{l}100 \\
\mathrm{ppm}\end{array}$ & $\begin{array}{l}100 \\
\mathrm{ppm}\end{array}$ & $\begin{array}{l}100 \\
\text { ppm }\end{array}$ & $\begin{array}{l}100 \\
\text { ppm }\end{array}$ & $\begin{array}{l}100 \\
\mathrm{ppm}\end{array}$ & $\begin{array}{l}100 \\
\text { ppm }\end{array}$ & $\begin{array}{l}100 \\
\text { ppm }\end{array}$ & $\begin{array}{l}100 \\
\mathrm{ppm}\end{array}$ & $\begin{array}{c}100 \\
\text { ppm }\end{array}$ & $\begin{array}{l}100 \\
\text { ppm }\end{array}$ & $\begin{array}{l}100 \\
\text { ppm }\end{array}$ & $\begin{array}{l}100 \\
\mathrm{ppm}\end{array}$ \\
\hline 0 & 0.234 & 0.234 & 0.234 & & 0 & 0.234 & 234 & 0.234 & 0.234 & & 0.234 & 0.23 & 0.234 & 0.234 \\
\hline 24 & $0.647^{\mathrm{a}}$ & $0.437^{\mathrm{k}}$ & $0.538^{\mathrm{h}}$ & $0.53^{\mathrm{h}}$ & $0.476^{\mathrm{j}}$ & $0.577^{\mathrm{e}}$ & $0.554^{\mathrm{g}}$ & $0.515^{\mathrm{i}}$ & $0.619^{c}$ & $0.585^{\mathrm{d}}$ & $0.569^{f}$ & $0.632^{\mathrm{b}}$ & $0.608^{c}$ & $0.593^{\mathrm{cd}}$ \\
\hline 48 & $1.131^{\mathrm{a}}$ & $0.749^{\mathrm{k}}$ & $0.803^{\mathrm{h}}$ & $0.772^{\mathrm{i}}$ & $0.764^{j}$ & $0.889^{\mathrm{e}}$ & $0.835^{\mathrm{g}}$ & $0.803^{h}$ & $0.998^{\mathrm{c}}$ & $0.905^{\mathrm{e}}$ & $0.858^{\mathrm{f}}$ & $1.061^{\mathrm{b}}$ & $0.983^{\mathrm{d}}$ & $0.920^{\mathrm{d}}$ \\
\hline 72 & $2.067^{\mathrm{a}}$ & $1.232^{\mathrm{k}}$ & $1.482^{\mathrm{h}}$ & $1.271^{\mathrm{i}}$ & $1.256^{\mathrm{j}}$ & $1.537^{\mathrm{e}}$ & $1.404^{\mathrm{g}}$ & $1.334^{\mathrm{h}}$ & $1.724^{c}$ & $1.568^{\mathrm{e}}$ & $1.451^{\mathrm{f}}$ & $1.895^{\mathrm{b}}$ & $1.732^{\mathrm{c}}$ & $1.669^{\mathrm{d}}$ \\
\hline 96 & $2.513^{\mathrm{a}}$ & $1.492^{\mathrm{k}}$ & $1.766^{\mathrm{h}}$ & $1.543^{\mathrm{j}}$ & $1.523^{\mathrm{jk}}$ & $1.866^{\mathrm{f}}$ & $1.705^{\mathrm{h}}$ & $1.623^{\mathrm{i}}$ & $2.106^{\mathrm{c}}$ & $1.9027^{\mathrm{e}}$ & $1.761^{\mathrm{g}}$ & $2.313^{\mathrm{b}}$ & $2.108^{\mathrm{c}}$ & $2.012^{\mathrm{d}}$ \\
\hline 120 & $3.11^{\mathrm{a}}$ & $1.823^{\mathrm{k}}$ & $2.167^{\mathrm{h}}$ & $1.879^{j}$ & $1.859^{\mathrm{jk}}$ & $2.288^{\mathrm{f}}$ & $2.084^{\mathrm{h}}$ & $1.983^{\mathrm{i}}$ & $2.59^{\mathrm{c}}$ & $2.335^{\mathrm{e}}$ & $2.155^{\mathrm{g}}$ & $2.856^{\mathrm{b}}$ & $2.595^{\mathrm{c}}$ & $2.475^{\mathrm{d}}$ \\
\hline
\end{tabular}

Values followed by the same letter in the same row are not significantly different $\mathrm{P} \leq 0.05$.

\section{Conclusion}

In summary, the results from this study have shown that methanol was the most suitable solvent for polyphenolic compounds extraction from salicornia fruticosa air part. Additionally, different extracts of air parts of salicornia fruticosa showed potent antioxidant activity lower than the standard BHA. The antioxidative activities observed can be attributed to presence of phenolic compounds. HPLC analysis for the total polyphenols extracted indicated to presence high percentages of Pyrogallol, Ellagic, B-OH Benzoic and Catechin. The extracted phenolic acids were tested on preservation of corn oil comparing with synthetic antioxidant (TBA) on the oil stability against oxidative rancidity during storage at $70{ }^{\circ} \mathrm{C}$ for 5 days. Results show that peroxide value and TBA values of corn oil that treated by different types of extracts at different levels were lower than control and the recommended concentration for natural antioxidants (methanolic extract) is $300 \mathrm{ppm}$.

\section{References}

Arai S, Morinaga Y, Yoshika T, Ichiishi E, Kiso Y and Yamazaki M (2002), Recent trends in functional foods science and industry in Japan. Bioscience Biotechnology and Biochemistry, 66(10): 2017-2029.

Bandoniene D, Pukalskas A, Venskutomis PR and Gruzdiene D (2000), Preliminary screening of antioxidants of some plants extracts in rapeseed oil. Food Research International, 23(9): 785-791.

Chavan UD, Shahidi F and Naczk M (2001), Extraction of condensed tannins from beach pea (Luthyrus maritimus L.) as affected by different solvents. Food Chemistry, 75: 509-512.

Duncan DB (1955), Multiple range and multiple F tests: Biometrics, 11:1- 42.

Evangelisti F, Zunin P, Tisconia E, Petacdchi R, Drava G, Lanteri S (1997), Stability to oxidation of virgin olive oils as related to olive conditions: Study of polar compounds by chemo metric methods. JAOCS. 74(8): 1017- 1022 .

Goli AH, Barzegar M and Sahari MA (2005), Antioxidant activity and total phenolic compounds of pistachio (Pistachia vera) hull extracts. Food Chemistry, 92: 521-525. 
Hassan Amal AAM (2002), Evaluation of some natural antioxidants and their effect on the quality of some foods. M.Sc. thesis. Food Industry and Dairy Science Dept., Fac. Of Agric. Minufiya Univ., Egypt.

Hou Z, Lambert JD, Chin KV and Yang, CS (2004), Effects of tea polyphenols on signal transduction pathways related to cancer chemoprevention. Mutation Research, 555: 3-19.

Kahkonen MP, Hopia AI, Vuorela HJ, Rauha J, Phlaza K, Kujala TS and Heinonen M (1999), Antioxidant activity of plant extracts containing phenolic compounds. $J$. Agric. Food Chem. 47: 3954- 3962.

Kang, S, Kim D, Lee, B, Kim M, Chiang, M and Hong, J (2011), Antioxidant properties and cytotoxic effect of fractions from glasswort (salicornia herbacea) seed extracts on human intestinal cells. Food Sci. Biotechnol. 20 (1): 115- 122.

Kim YA, Kong, CS Um, YR, Lim SY, Yea SS and Seo YJ (2009), Constituents of the halophyte Salicornia herbacea. Med. Food. 12: 661.

Laandrault N, Pouchert P, Ravel P, Gase F, Cros G and Teissedro PL (2001), Antioxidant activities and phenolic level of French wines from different varieties and vintages. Journal of Agricultural and Food Chemistry, 49: 3341-3343.

Lee YS, Lee HS, Shin KH, Kim BK and Lee S (2004), Constituents of the halophyte Salicornia herbacea. Arch. Pharm. Res. 27: 1034-1036.

Leonard WA, Woods AE and Wells MK (1987), Food composition and analysis. Published by van Nostrand Reinhold company, New York. 221- 269.

McGrath RM, Kaluza WZ ,Daiber KH, Vander Riet WB and Glennie CW (1982), Polyphenols of sorghum grain, their changes during malting, and their inhibitory nature. J. of Agric. and food Chem., 30: 450.

Min JG, Lee DS, Kim TJ, Park JH, Cho TY and Park DI (2002), Chemical composition of Salicornia herbacea L. J. Food Sci. Nutr. 7: 105-107.

Min JG, Son KT, Kim JH, Kim TJ and Park JH (2002), Physiological and functional peopertoes of Salicornia herbacea (Tungtungmadi) leaf extracts. Nutraceuticals and Food 7: 261-264.

Moure A, Cruz JM, Franco D, Dominguez JM, Sineiro J and Dominguez H (2001), Natural antioxidants from residual sources. Food Chemistry, 72: 145-171.
Panico AM, Cardile V, Garufi F, Puglia C, Bonina F and Ronsisvalle G (2005), Protective effect of Capparis spinosa on chondrocytes. Life Sciences, 77: 2479-2488.

Peuchant E, Brun J, Rigalleau V, Dubourg, L, Thomas M and Daniel J (2004), Oxidative and antioxidative status in pregnant women with either gestational or type 1 diabetes. Clinical Biochemistry, 37: 293-298.

Radwan HM, Nazif NM and Abou-Setta LM (2007), Phytochemical Investigation of Salicornia fruticosa (L.) and Their Biological Activity. Research Journal of Medicine and Medical Sciences, 2(2): 72-78.

SAS (Statistical Analysis System) (1988). SAS / STAT user's guide release 6.03 edition. SAS Institute Inc. Cary, North Carolina, USA.

Sasidharan S, Darah I, Mohd Jain Noordin MK (2007), Free radical Scavenging Activity and Total Phenolic Compounds of Gracilaria changii. Int. J. Nat. Eng. Sci., 1(3): 115-117.

Sidwell CG, Salwin H, Benca M and Mitechell JH (1990), The use of Thiobarbituric acid as a measurement of fat oxidation. AOCS, 3(12):603-606.

Sousa A, Ferreira ICFR, Barros L, Bento A and Alberto J (2008), Effect of solvent and extraction temperatures on the antioxidant potential of traditional stoned table olives "alcaparras". LWT, 41: 739-745.

Spignoli G (2000), Protective effects of dietary flavonoids on cardiovascular system and circulation. European Bulletin of Drug Research, 8: 1-8.

Tsuda T, Watanabe M, Ohshima K, Yamamoto A, Kawakishi S and Osawa T (1998), Antioxidant components isolated from the seeds of tamarind (Tamarindus Indica L.). Journal of Agricultural and Food Chemistry, 42: 2671-2674.

Yanping W, Mourning Z, Yuhang, Z and Zhying, P (1999), Study on effect of different antioxidants on antioxidant properties oils. Bioresource Tech. 24: 37-39.

Zuo Y, Chen H and Deng, Y (2002), Simultaneous determination of catechins, caffeine and gallic acids in green, oolong, black and pureh teas using HPLC with a photodiode array detector. Talanta, 57: 307-316.

Received: 07 April 2013; Revised: 04 November 2013, Accepted: 02 January 2014. 